\section{Induction, maintenance and recovery charac- teristics of desflurane in infants and children}

To determine the induction and recovery characteristics of the new poly-fluorinated anaesthetic desflurane, 78 fasting and unpremedicated neonates, infants and children up to 12 y r of age were studied. Patients were stratified according to age: full-term neonates $<28$ days of age $(n=12)$, infants $1-6$ mih $(n=12)$ infants 6-12 mth $(n=15)$, children $1-3$ yr $(n=15), 3-5$ yr $(n=$ $12)$, and 5-12 yr $(n=12)$. After preoxygenation for two minutes and an awake tracheal intubation, neonates were anaesthetized with stepwise increases in the inspired concentration of desflurane in an airloxygen mixture. Infants $1-12 \mathrm{mth}$ of age and children were anaesthetized with stepwise increases in the inspired concentration of desflurane in oxygen. Their tracheas were intubated under deep desflurane anciesthesia without muscle relaxation. The incidence of ainway reflex responses (including breathholding, coughing, laryngospasm, bronchospasm and oropharyngeal secretions), incidence of excitement, minimum arterial oxygen saturation, and times to loss of eyelash reflex and tracheal intubation during induction were recorded. After skin incision, anaesthesia was maintained with desflurane $(\approx 1 \mathrm{MAC})$ in $60 \%$ nitrous oxide and oxygen. Heart rate and systolic arterial pressure were recorded awake, at $\approx 1 M A C$ before and after skin incision and throughout surgen: At the completion of surgery, all anaesthetics were discontinued and

\section{Key words}

ANAESTHESIA: paediatric;

ANAESTHETICS, VOLATILE: desflurane;

COMPLICATIONS: airway, bronchospasm, laryngospasm, secretions

MONITORING: arterial oxygen saturation.

From the Department of Anesthesia and the Research Institute, The Hospital for Sick Children, University of Toronto, Ontario. Supported, in part, with a grant from Anaquest, BOC Inc. Presented in part at the annual meeting of the American Society of Anesthesiology, Las Vegas, 1990.

Address correspondence to: Dr. Jerrold Lerman, Department of Anaesthesia, The Hospital for Sick Children, 555 University Avenue, Toronto, Ontario, Canada M5G 1 X8.

Accepted for publication 29th August, 1991. the lungs were ventilated with 100\% oxygen. During emergence, the end-ridal concentration of desflurane was recorded until extubation. The incidence of ainvay reflex responses and the times to eye opening and extubation after the discontinuation of desflurane were recorded. We found that during induction of anaesthesia, breathholding occurred in $50 \%$ of patients, coughing in $36 \%$, moderate or severe laryngospasm in $30 \%$ and secretions that required suctioning in $7.6 \%$. Excitement occurred in $100 \%$ of infants and children. Arterial oxygen saturation (mean $\pm S D$ ) decreased to $<90 \%$ in $18 \%$ of children. The time (mean $\pm S D$ ) from commencement of desflurane to loss of the eyelash reflex was $1.2 \pm 0.4$ min and to tracheal intubation, 4.6 \pm 1.2 min. Heart rate and systolic arterial pressure were stable throughout surgery. The washout of desflurane did not differ among the six groups. FAFAO was $0.14 \pm 0.05$ at two minutes and $0.06 \pm 0.04$ at five minutes after discontinuation of desflurane. The time from discontinuation of desflurane to extubation was greater in neonates, $6.6 \mathrm{~min}$, than it was in older infants and children, 4.5 to $5.8 \mathrm{~min}$. after approximately $45 \mathrm{~min}$ of surgery $(P<0.05)$. None of the patients demonstrated airway reflex responses after extubation. We conclude that although desflurane is not suited for induction of anaesthesia in infants and children, it maintains haemodynamic stability during surgery and facilitates a rapid recovery of consciousness without triggering ainway reflex responses.

Afin de déterminer les charactéristiques d'induction et de récupération d'un nouvel anesthésique polyfluoré, le desflurane, 78 nouveau-nés non-prémédiqués à jeun, nourrissons et enfants jusqu'à l'âge de 12 ans furent étudiès. Les patients furent stratifiés selon l'âge: nouveau-né à terme $<28$ jours d'âge $(n=$ J2), bébé de 1-6 mois $(n=12)$, enfant de 6-12 mois $(n=15)$, enfant de $1-3$ ans $(n=15), 3-5$ ans $(n=12)$, et $5-12$ ans $(n=$ 12). Après une préoxygénation de deux minutes et une intubation trachéale réveillée, les nouveau-nés furent anesthésiés avec du desflurane à des concentrations inspirées croissantes dans un mélange d'air/oxygène. Les bébés âgés de 1-12 mois et les enfants furent anesthésiés avec des concentrations croissantes de desflurane et oxygène. Leur trachée fut intubée sous anesthésie profonde au desflurane sans relaxant musculaire. L'incidence de réflexe des voies aériennes (incluant la rétention de la respiration, la toux, le laryngospasme, le bronchospasme et les sécré- 
tions oropharyngées), l'incidence de stimulation, de diminution de la saturation artérielle en oxygène, et les temps de perte du réflexe ciliaire et le temps d'intubation trachéale durant l'induction durent enregistrés. Après l'incision cutanée, l'anesthésie fut maintenue avec le desflurane (environ I MAC) avec 60\% de protoxyde d'azote et oxygène. La fréquence cardiaque et la pression artérielle systolique furent enregistrées en période de réveil, à environ I MAC avant et après l'incision cutanée et à travers la chirurgie. A la fin de la chirurgie, tous les anesthésiques furent cessés et les poumons furent ventilés avec $100 \%$ d'oxygène. Durant l'émergence, la concentration en fin d'expiration de desflurane fut enregistrée jusqu'à l'extubation. L'incidence des réponses réflexes des voies aériennes et les temps d'ouverture des yeux et l'extubation après la cessation du desflurane furent enregistrés. On a trouvé que durant l'induction de l'anesthésie, la rétension de la respiration est survenue chez $50 \%$ des patients, la toux chez $36 \%$, le lanyngospasme sévère ou modéré chez $30 \%$ et des sécrétions ayant requis la succion chez. 7.6\%. L'excitation fut observée chez $100 \%$ des bébés et enfants. La saturation artérielle d'oxygène (moyenne $\pm S D$ ) a diminué à un niveau $<\dot{a} 90 \%$ chez $18 \%$ des enfants. Le temps (moyenne \pm $S D)$ du début de l'administration du desflurane jusqu'à la perte du réflexe ciliaire était de $1,2 \pm 0,4$ min et pour l'intubation trachéale, 4,6 $\pm 1,2 \mathrm{~min}$. La fréquence cardiaque et la pression artérielle systolique furent stables à travers la chirurgie. Le lavage washout du desflurane n'était pas différent entre les six groupes. La FNFAO était de 0,14 $\pm 0,05$ à deux minutes et de $0,06 \pm 0,04$ à cinq minutes après cessation du desflurane. Le temps à partir de la cessation du desflurane jusqu'à l'extubation était plus grand chez les nouveau-nès, 6,6 min que chez les bébés plus âgés et les enfants, 4,5 à 5,8 min après approximativement 45 minutes de chirurgie $(P<0,05)$. Aucun des patients n'a démontré les réponses réflexes des voies aériennes après extubation. On conclut que même si le desflurane n'est pas convenable pour l'induction de l'anesthésie chez les bébés et enfants, il maintient une stabilité hémodynamique durant la chirurgie et facilite une récupération rapide de la conscience sans stimuler les réponses réflexes des voies aériennes.

Desflurane (I-653) is a new poly-fluorinated methyl ethyl ether anaesthetic that is similar in structure to isoflurane except for the substitution of a fluoride ion for chloride at the alpha ethyl carbon. This single substitution confers physical properties that differ from those of isoflurane including a lower boiling point $\left(23.5^{\circ} \mathrm{C}\right)$, lower blood/gas (0.42), brain/blood (1.3), and fat/blood (27) partition coefficients and decreased potency (MAC in infants and children ranges from $8.0-10.0 \%) .{ }^{1-3}$ Its low solubility in blood and tissues should facilitate a rapid wash-in and wash-out of alveolar and therefore tissue partial pressures of desflurane. ${ }^{4,5}$ These characteristics, together with preliminary evidence that at $1 \times$ MAC and sub-MAC desflurane, desflurane is devoid of irritant effects on the respiratory system in adults suggest that this new inhalational anaesthetic may have a role in paediatric anaesthesia. $^{6}$

Desflurane has been investigated extensively in humans. It is less potent than other inhalational anaesthetics: MAC is $7.25 \%$ in young adults and $6.0 \%$ in older adults. ${ }^{7}$ Based on these data, cardiovascular, ${ }^{8}$ respiratory ${ }^{9}$ and metabolic ${ }^{10}$ studies in adults have established its safety for use in adult humans. Thus, we undertook this study to determine the suitability of desflurane for induction and maintenance of anaesthesia and the quality and speed of emergence in infants and children.

\section{Methods}

With approval from the local Human Subjects Review Committee, written informed consent was obtained from the parents of 78 unpremedicated neonates, infants and children who were scheduled for minor surgery (defined as an anticipated blood loss $<10 \%$ of the blood volume). The types of surgery included congenital defects of the gastrointestinal and urological systems in the neonates and superficial lower abdominal surgery and plastic surgery in infants and children. All patients were ASA physical status I or II, fasted and unpremedicated. All patients were monitored with a continuous ECG, pulse oximeter, endtidal and inspired carbon dioxide and desflurane concentrations as well as an automated blood pressure cuff, precordial stethoscope, and temperature probe. For neonates, the tracheas were intubated while they were awake. Anaesthesia was then induced with desflurane in an air/oxygen mixture. For infants and children, anaesthesia was induced by inhalational induction with desflurane in $95 \%$ oxygen and $5 \%$ nitrogen. The inspired concentration of desflurane was increased in increments of $7 \%$ every three or four breaths up to a maximum inspired concentration of $20-25 \%$. When the airway was controlled by manual ventilation, the inspired concentration was decreased to $12-15 \%$ and the trachea was intubated without muscle relaxation. Desflurane was delivered by a modified DM 5000 anaesthetic machine and a pressurized vaporizer. After intubation, ventilation was controlled using an Ohmeda 7000 or Air Shields ventilator to maintain an end-tidal $\mathrm{pCO}_{2}$ between 35 and $45 \mathrm{mmHg}$. All patients were supine and horizontal during the induction period. As soon as the eyelash reflex was lost, intravenous access was established. Lactated Ringer's solution or $5 \%$ albumin $\left(5-15 \mathrm{ml} \cdot \mathrm{kg}^{-1}\right)$ was administered intravenously to maintain systolic pressure $>40 \mathrm{mmHg}$ in neonates and $>60 \mathrm{mmHg}$ in older infants and children during the preincision period. Atropine and neuromuscular blocking drugs were avoided. Temperature was maintained between 35.5 and $37.5^{\circ} \mathrm{C}$ by prewarming the operating room for 
TABLE I Induction characteristics

\begin{tabular}{|c|c|c|c|c|c|c|c|c|c|c|}
\hline Group & $\begin{array}{l}\text { No. of } \\
\text { patients }\end{array}$ & Age* & $\begin{array}{l}\text { Weigh * } \\
(k g)\end{array}$ & $\begin{array}{l}\text { Brearh- } \\
\text { holding }\end{array}$ & Coughing & $\begin{array}{l}\text { Laryngo- } \\
\text { spasm }\end{array}$ & $\begin{array}{l}\text { Broncho- } \\
\text { spasm }\end{array}$ & Secretions & $\begin{array}{l}\text { Lowest } \\
\text { arterial } \\
\text { saturation } \\
(\%) \dagger\end{array}$ & $\begin{array}{l}\text { Incidence } \\
\text { of } \\
\text { saruration } \\
<90 \% t\end{array}$ \\
\hline \multicolumn{11}{|l|}{ Infants } \\
\hline $1-6 \mathrm{mth}$ & 12 & $2.8 \pm 1.3$ & $5.7 \pm 0.9$ & 5 & 1 & 2 & 0 & 0 & $93.3 \pm 6.8$ & 3 \\
\hline $6-12 \mathrm{mth}$ & 15 & $8.3 \pm 1.7$ & $8.9 \pm 1.3$ & 5 & 5 & 2 & 0 & 2 & $93.8 \pm 7.7$ & 3 \\
\hline \multicolumn{11}{|l|}{ Children } \\
\hline $1-3$ yг & 15 & $1.8 \pm 0.6$ & $12.5 \pm 1$ & 9 & 8 & 6 & 0 & 2 & $91.7 \pm 7.9$ & 5 \\
\hline $3-5 \mathrm{yr}$ & 12 & $3.7 \pm 0.6$ & $15.1 \pm 1.6$ & 6 & 5 & 6 & 0 & 0 & $96.2 \pm 4.0$ & 1 \\
\hline $5-12 y r$ & 12 & $7.5 \pm 1.7$ & $25.7 \pm 7.2$ & 8 & 5 & 4 & 0 & 1 & $95.7 \pm 2.6$ & 0 \\
\hline Total & 66 & & & $33(50)$ & $24(36)$ & $20(30)$ & $0(0)$ & $5(7.5)$ & $94.1 \pm 6.3$ & $12(18)$ \\
\hline
\end{tabular}

Number of patients with moderate or severe signs (see text for description).

() percent of patients.

*Data are means $\pm S D$.

tDuring induction of anaesthesia.

neonates and infants $1-6$ months of age, interposing a heat and moisture exchange device (Humid-vent, Gibeckß) between the elbow connector of the T-piece and the fresh gas line, and positioning all patients on a warming blanket.

For infants and children, the incidence of moderate or severe airway reflex responses including breathholding $(>15 \mathrm{sec})$, coughing ( $>2$ episodes), laryngospasm ( $>5$ $\mathrm{sec}$ of phonation or inability to ventilate), bronchospasm (bilateral wheezing), and secretions (requiring suctioning), in addition to the incidences of excitement, hypotension and arterial oxygen desaturation were recorded during induction of anaesthesia. The times from the start of desflurane to loss of eyelash reflex and intubation were also recorded. Heart rate and systolic arterial pressure were recorded awake, at $\approx 1 \mathrm{MAC}$ before and after skin incision and every five minutes during maintenance. ${ }^{3}$ The mean $( \pm S D)$, maximum and minimum heart rates and systolic arterial pressures during maintenance were recorded for each patient and mean ( \pm SD) values for each age group reported. Hypotension was defined as a $>30 \%$ decrease in systolic arterial pressure from awake to preincision measurements.

End-tidal gas was sampled through a 19 standard wire gauge Deseret Intracath $\circledast$ catheter inserted through the elbow connector to within $1 \mathrm{~cm}$ of the distal end of the tracheal tube. The catheter hub was fitted tightly into the elbow connector. The end-tidal concentrations of desflurane and carbon dioxide were measured continuously with a calibrated infra-red analyzer (Datex 254 Airway Gas Monitor, Helsinki, Finland).

After skin incision, anaesthesia was maintained with $7-12 \%$ desflurane and $60 \% \mathrm{~N}_{2} \mathrm{O}$ in oxygen. Ventilation was controlled to maintain normocapnia. During surgery, the end-tidal concentration of desflurane was decreased towards the concentration used at the time of skin incision as tolerated by the patient (that is, to maintain heart rate and systolic arterial pressure within $20 \%$ of baseline measurements). At the completion of surgery, desflurane and nitrous oxide were discontinued and ventilation continued with $100 \%$ oxygen to maintain normocapnia until extubation. During emergence, the end-tidal concentration of desflurane $\left(F_{A}\right)$ was recorded on a Psion LZ64 computer " cvery ten seconds until extubation. The washout of desflurane was the ratio of the FA to the endtidal concentration of desflurane at the cessation of anaesthesia ( $\left.F_{A O}\right)$ against time for each of the six age groups. The times to eye opening, extubation and full recovery (defined as fully alert, oriented and vital signs stable) after discontinuation of desflurane were recorded. The incidence of airway reflex responses during emergence was also recorded.

Rectal acetaminophen $\left(10-15 \mathrm{mg} \cdot \mathrm{kg}^{-1}\right)$ was administered to neonates and intramuscular codeine ( 1.5 $\mathrm{mg} \cdot \mathrm{kg}^{-1}$ ) to older infants and children for objective pain scores exceeding $6 .^{12}$

Statistical significance of $P<0.05$ was accepted. Intragroup comparisons were analyzed by repeated-measures ANOVA and the Newman-Keuls multiple range test. Intergroup comparisons of parametric data (times, age and weight) were analyzed by one-way ANOVA and the Student-Newman-Keuls test. Intergroup comparisons of nominal data were analyzed using Fisher's exact test or Chi-square analysis.

\section{Results}

Induction characteristics were evaluated in 66 infants $(>1$ 
TABLE II Induction characteristics

\begin{tabular}{|c|c|c|c|c|c|}
\hline Group & $\begin{array}{l}\text { Face mask to loss } \\
\text { of eyelash reflex } \\
\text { (min) }\end{array}$ & $\begin{array}{l}\text { Face mask } \\
\text { to intubation } \\
\text { (min) }\end{array}$ & $\begin{array}{l}\text { Mean \% decrease } \\
\text { in SAP\$ }\end{array}$ & $\begin{array}{l}\text { Incidence of } \\
\text { hypotensiom } \$ \\
(\%)\end{array}$ & Arrhythmias \\
\hline Neonates & - & - & 34 & 42 & - \\
\hline \multicolumn{6}{|l|}{ Infants } \\
\hline $1-6 \mathrm{mth}$ & $1.0 \pm 0.4^{*}$ & $3.8 \pm 1.0$ & 34 & 58 & I \\
\hline $6-12 \mathrm{mth}$ & $0.9 \pm 0.2^{*}$ & $4.3 \pm 1.1$ & 26 & 42 & 0 \\
\hline \multicolumn{6}{|l|}{ Children } \\
\hline $1-3 \mathrm{yr}$ & $1.1 \pm 0.2^{*}$ & $5.3 \pm 1.3 \ddagger$ & 28 & 25 & 1 \\
\hline $3-5$ уг & $1.2 \pm 0.3 \dagger$ & $4.2 \pm 0.9$ & 27 & 42 & 0 \\
\hline $5-12 y r$ & $1.7 \pm 0.7$ & $5.2 \pm 1.1 \ddagger$ & 22 & 17 & 1 \\
\hline Total & $1.2 \pm 0.4$ & $4.6 \pm 1.2$ & $29 \pm 13 \%$ & $38 \%$ & $3(4.5)$ \\
\hline
\end{tabular}

Data are means \pm SD.

$* P<0.001$ compared with $5-12 \mathrm{yr}$

$+P<0.005$ compared with $5-12$ yr

$\ddagger P<0.01$ compared with infants $1-6$ mos.

$\$ A t \approx 1$ MAC before skin incision compared to awake values.

month of age) and children while recovery characteristics were evaluated in 78 neonates, infants and children (Tables I-IV). Breathholding, coughing and laryngospasm occurred in all age groups (Table I). Laryngospasm was managed with continuous positive airway pressure and $100 \%$ oxygen until manual ventilation was established. This was successful in all patients except two (incidence of $3 \%$ ) who required succinylcholine. Both of these children had histories of recent upper respiratory tract infections and both episodes occurred early in our experience with desflurane. Bronchospasm did not occur in any infants and children. This high incidence of airway reflex responsiveness was associated with a transient decrease in $\mathrm{SaO}_{2}$ to $<90 \%$ in $18 \%$ of patients (Table I). Although the eyelash reflex was lost rapidly, the time to intubation was prolonged as a result of the airway reflex responses (Table II). All infants and children (>1 month of age) demonstrated a period of excitement that lasted more than 15 seconds and required restraint. Secretions were not a problem.

The intubating conditions were rated as good in all infants and children; that is, the vocal cords were in the mid-position and motionless during laryngoscopy.

Compared with awake values, heart rate decreased significantly pre-incision in infants $6-12 \mathrm{mth}$ and children 1-3 and 3-5 yr, but returned to or above awake values post-incision (Table III). ${ }^{3}$ Mean heart rate during maintenance was similar to awake values except in infants 6-12 months of age. There were no instances of bradycardia. Nodal rhythms occurred during the induction in three patients: ages $4 \mathrm{mth}, 2.5 \mathrm{yr}$ and $8 \mathrm{yr}$ (Table I). In the last two patients, the arrhythmias were temporally related to traction on the spermatic cord. All three arrhythmic episodes disappeared without therapeutic intervention.

Compared with awake values, systolic arterial pressure decreased pre-incision in all age groups and remained below awake values post-incision in neonates, infants 6-12 mth and children 5-12 yr of age (Table $11 \mathrm{I}) .^{3}$ The mean percentage decrease in systolic arterial pressure from awake values to $\approx 1 \times$ MAC desflurane before incision was $29 \pm 13 \%$ (Table II). The incidence of hypotension was greatest in infants $(58 \%)$ and least in children 5-12 yr of age $(17 \%){ }^{3}$ Systolic arterial pressure remained significantly below awake values throughout the maintenance period in all age groups, although the pressures did not warrant intervention (Table III).

The duration of anaesthesia during the maintenance period was similar in all age groups (Table IV). At the discontinuation of anaesthesia, the concentration of desflurane decreased rapidly reaching an $F_{A} / F_{A O}$ of 0.14 by two minutes and 0.06 by five minutes (Table IV) (Figure). Upon extubation, recovery from desflurane was rapid. There were no instances of adverse airway reflex responses after extubation. Postoperative analgesia was administered immediately after extubation but before the patients left the operating room because the objective pain scores were $>6$ in all patients immediately after extubation.

\section{Discussion}

To effect a rapid induction of anaesthesia, the ideal inhalational anaesthetic must be: (1) relatively insoluble in blood and tissues and (2) non-irritating to the airway. Halothane, an anaesthetic that is moderately soluble in 
TABLE III Haemodynamic responses

\begin{tabular}{|c|c|c|c|c|c|c|}
\hline \multirow[b]{2}{*}{ Age Group: } & \multicolumn{6}{|c|}{ Heart rate (beats $\cdot \min ^{-1}$ ) } \\
\hline & Awake* & Pre-incision* & Post-incision* & Maintenance & Minimum $\dagger$ & Maximum $t$ \\
\hline Nconales & $154.2 \pm 29$ & $1.52 .5 \pm 14.1$ & $160.7 \pm 22.6$ & $153.1 \pm 22.6$ & 146.3 & 158.1 \\
\hline \multicolumn{7}{|l|}{ Infants } \\
\hline $1-6 \mathrm{mth}$ & $149.1 \pm 22.0$ & $148.3 \pm 22.8$ & $160.8 \pm 20.2 \|$ & $139.2 \pm 20.6$ & 132.2 & 147.8 \\
\hline $6-12 \mathrm{mth}$ & $166.4 \pm 23.3$ & $139.6 \pm 15.3 \ddagger$ & $161.0 \pm 18.3$ & $135.1 \pm 14.2 \|$ & 125.9 & 144.6 \\
\hline \multicolumn{7}{|l|}{ Children } \\
\hline $1-3 \mathrm{yr}$ & $138.1 \pm 29.5$ & $119.7 \pm 14.9 \ddagger$ & $146.7 \pm 29.6$ & $123.3 \pm 18.1$ & 114.1 & 1.32 .3 \\
\hline $3-5 \mathrm{yr}$ & $130 \pm 28.0$ & $106.4 \pm 15.4 \S$ & $144.9 \pm 25.7$ & $116.6 \pm 13.4$ & 106.5 & 128.8 \\
\hline $5-12 \mathrm{yr}$ & $97.9 \pm 23$ & $92.7 \pm 13.1$ & $123.3 \pm 18.4$ & $97.1 \pm 7.0$ & 87.1 & 110.3 \\
\hline
\end{tabular}

\begin{tabular}{|c|c|c|c|c|c|c|}
\hline \multirow[b]{2}{*}{ Age Group: } & \multicolumn{6}{|c|}{ Systolic arterial pressure $(\mathrm{mmHg})$} \\
\hline & Awake* & Pre-incision* & Post-incision* & Maintenance & Minimum & Maximumt \\
\hline Neonates & $83.4 \pm 16.9$ & $53.8 \pm 12.4 \|$ & $59.8 \pm 12.4 \|$ & $55.5 \pm 16.2 \|$ & 50.8 & 61.2 \\
\hline \multicolumn{7}{|l|}{ Infants: } \\
\hline $1-6 \mathrm{mth}$ & $112.0 \pm 26.1$ & $73.3 \pm 23.1 \|$ & $80.4 \pm 20.8$ & $72 \pm 19.2 \|$ & 66.8 & 78.8 \\
\hline $6-12$ mth & $99.6 \pm 17.3$ & $76.6 \pm 12.6 \|$ & $89.2 \pm 19.2 f$ & $80.9 \pm 11.8 \$$ & 74.2 & 88 \\
\hline \multicolumn{7}{|l|}{ Children } \\
\hline $1-3 y r$ & $111 \pm 17.4$ & $88.2 \pm 12.9 \S$ & $109 \pm 23.9$ & $98.6 \pm 12.8 \div$ & 90.4 & 100.7 \\
\hline $3-5 y r$ & $115.4 \pm 19$ & $84.3 \pm 8.4 \|$ & $105.2 \pm 15$ & $91.9 \pm 12.7 \S$ & 84.9 & 100.4 \\
\hline $5-12 y r$ & $117.7 \pm 15$ & $90.3 \pm 8.4 \|$ & $105.7 \pm 13.8 \mathrm{f}$ & $96.3 \pm 7.2 \|$ & 89.6 & 105.8 \\
\hline
\end{tabular}

Data are means \pm SD.

*Data published previously graphically. ${ }^{3}$

†Mean values during maintenance.

$\ddagger P<0.05$ compared with awake valucs.

$\$ P<0.025$ compared with awake values.

$P<0.005$ compared with awake values.

$\| P<0.001$ compared with awake values.

blood and tissues and relatively non-irritating to the airway, is the most common inhalational agent for induction of anaesthesia in infants and children. Although isoflurane has a blood solubility that is only one-half that of halothane, ${ }^{13}$ its irritant effects on the respiratory tract offset any potential effects conferred by its low blood solubility. ${ }^{14-17}$ The physico-chemical properties of desflurane favour an even more rapid induction and recovery of anaesthesia than isoflurane $e^{1,2}$ and if desflurane were devoid of irritant effects on the airway in children as it is in adults, ${ }^{6}$ then this anaesthetic could have an important role in paediatric anaesthesia.

However, like isoflurane, desflurane irritates the respiratory tract in children. The results of this study indicate that, although consciousness is lost rapidly with desflurane (as evidenced by the rapid loss of the eyelash reflex) breathholding, coughing and laryngospasm delay the onset of deeper levels of anaesthesia. Moreover, these airway reflex responses lead to significant arterial oxygen desaturation. Based on these data, desflurane, like isoflurane, would seem to be an unsatisfactory induction agent in infants and children. However, these conclusions could be viewed as unfair to desflurane since this study was conducted under austere conditions; that is, anaesthesia was induced with desflurane and oxygen alone. It is possible that the use of adjuvants such as premedicants, ${ }^{18,19}$ nitrous oxide, ${ }^{20}$ anticholinergic drugs ${ }^{21}$ and scented masks could have attenuated the irritant effects of desflurane on the respiratory tract. Recent data, however, would suggest that at least two of these, premedicants and nitrous oxide, do not ameliorate the irritant effects of desflurane on the respiratory tract. ${ }^{22}$

Anaesthesia was induced rapidly with desflurane as evidenced by the rapid loss of eyelash reflex (Table II). The time to loss of the eyelash reflex in this study compares favourably with previous data for isoflurane and halothane ${ }^{16,23}$ as predicted by the lower blood and tissue solubilities of desflurane. ${ }^{1,2}$ However, differences between 
TABLE IV Recovery characteristics

\begin{tabular}{|c|c|c|c|c|c|c|}
\hline Group & $\begin{array}{l}\text { Duration of } \\
\text { maintenance } \\
\text { anaesthesiat } \\
(\text { min) }\end{array}$ & $\begin{array}{l}F N F_{A O} \\
\text { at } 2 \text { minutes } \\
\text { of washout }\end{array}$ & $\begin{array}{l}F, \sqrt{ } F_{A O} \\
\text { at } 5 \text { minutes } \\
\text { of washous }\end{array}$ & $\begin{array}{l}\text { End of desflurane } \\
\text { to exrubation } \\
\text { (min) }\end{array}$ & $\begin{array}{l}\text { End of desflurame } \\
\text { to eye opening } \\
\text { (min) }\end{array}$ & $\begin{array}{l}\text { Time to full } \\
\text { recovery } \\
\text { (min) }\end{array}$ \\
\hline Neonates & $53.1 \stackrel{26.5}{-1}$ & $0.16 \pm 0.04$ & $0.08 \pm 0.03$ & $6.6 \pm 1.6$ & - & $26.7 \pm 15.6$ \\
\hline \multicolumn{7}{|l|}{ Infants } \\
\hline $1-6 \mathrm{mth}$ & $63.8 \pm 52.0$ & $0.14 \pm 0.05$ & 0.05 & $4.7 \pm 1.4^{*}$ & $6.2 \pm 2.6$ & $31.2 \pm 12.3$ \\
\hline $6-12 \mathrm{mth}$ & $45.6 \pm 27.1$ & $0.14 \pm 0.04$ & 0.00 & $4.5 \pm 1.3^{*}$ & $5.6 \pm 1.8$ & $35.0 \pm 13.0$ \\
\hline \multicolumn{7}{|l|}{ Children } \\
\hline $1-3 y r$ & $42.5 \pm 18.9$ & $0.12 \pm 0.07$ & $0.04 \pm 0.03$ & $5.1 \pm 1.3^{*}$ & $5.4 \pm 1.2$ & $29.7 \pm 8.8$ \\
\hline $3-5$ yr & $58.3 \pm 48.2$ & $0.15 \pm 0.05$ & $0.08 \pm 0.03$ & $5.8 \pm 1.3$ & $7.0 \pm 3.3$ & $26.3 \pm 9.3$ \\
\hline $5-12 \mathrm{yr}$ & $54.9 \pm 29.1$ & $0.13 \pm 0.06$ & $0.12 \pm 0$ & $5.5 \pm 1.6$ & $6.8 \pm 1.8$ & $27.9 \pm 9.4$ \\
\hline Total & $51.8 \pm 35.2$ & $0.14 \pm 0.05$ & $0.06 \pm 0.04$ & $5.3 \pm 1.5$ & $6.1 \pm 2.2$ & $29.7 \pm 11.6$ \\
\hline
\end{tabular}

Data are means $\pm S D$.

$* P<0.025$ compared with neonates.

$\dagger$ Time from intubation to discontinuation of desflurane.

$¥$ Time from extubation until alen, oriented and vital signs stable.

$F A$ is the alveolar fraction of desflurane.

FAO is the alveolar fraction of desflurane at the time of discontinuation of anaesthesia.

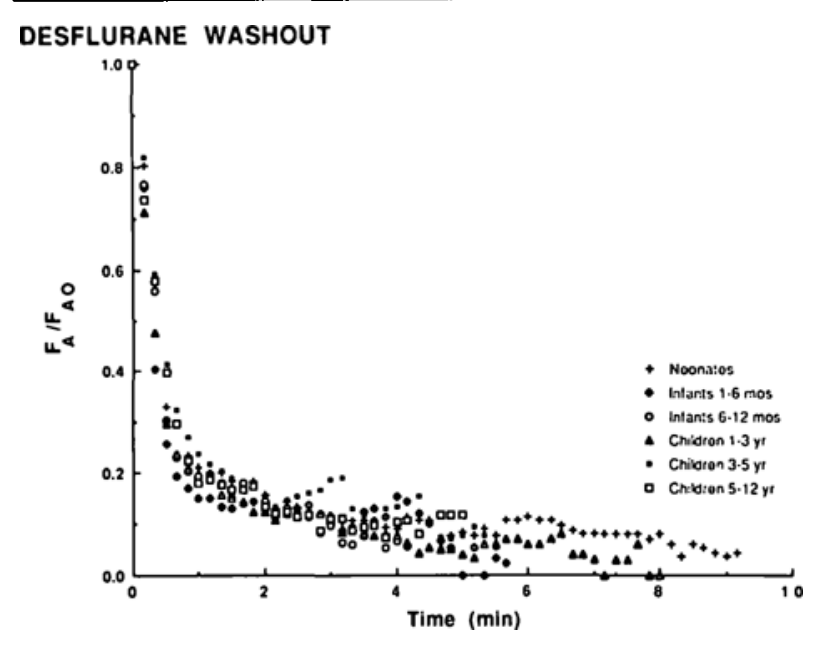

FIGURE Washout of desflurane in neonates, infants and children up to 12 yr of age. All patients received $100 \%$ oxygen and the lungs were ventilated to normocapnia. The washout is shown as the ratio of $F_{A}$ FAO where $F_{A}$ is the alveolar fraction of desflurane during the washout period and $F_{A O}$ is the alveolar fraction of desflurane prior to the cessation of anaesthesia.

this study and previous induction studies preclude direct comparisons of the induction times.

Although the eyelash reflex was lost rapidly during induction of anaesthesia with desflurane, deep anaesthesia was achieved only after a period of increased airway reflex responses and excitement and in $18 \%$ of patients, arterial oxygen desaturation below $90 \%$. This is similar to the results of studies with isoflurane in children. ${ }^{14.16 .17} \mathrm{We}$ sought to speed the rate of induction of anaesthesia with desflurane by increasing the inspired concentration as rapidly as tolerated. The tolerance was limited by the severity of the excitement period and the airway reflex responses. We found that all patients developed a period of excitement regardless of the rate of increase of desflurane concentration. We also found that when the inspired concentration of desflurane was increased slowly, the airway reflex responses were exaggerated. This latter observation is consistent with the experience of Fisher $\boldsymbol{e t}$ al. (who reported a $73 \%$ incidence of laryngospasm during induction of anaesthesia with desflurane)." In order to minimize the incidence and severity of airway reflex responses during induction of anaesthesia with desflurane and oxygen, we increased the inspired concentration of desflurane in increments of $7 \%$ every three to four breaths from zero to a maximum of $20-25 \%$ within $60-90 \mathrm{sec}$.

Haemodynamic stability is an important characteristic for any inhalational anaesthetic. Studies in both swine ${ }^{24}$ and adults ${ }^{8}$ indicate that desflurane decreases systolic arterial pressure to a similar extent as isoflurane. The decrease in systolic arterial pressure may be attributed to a decrease in systemic vascular resistance. In the present study, systolic arterial pressure decreased in neonates and infants to a similar extent as that reported previously with halothane at equipotent concentrations in the same two age groups. ${ }^{25}$ However, we were surprised by the high in-

'DM Fisher (personal communication). 
cidence of hypotension before incision, although none of these episodes required intervention. We considered the high incidence of hypotension in part, artifactual since the awake systolic arterial pressure measurements in these unpremedicated patients were at or above the upper limits of normal values. These data indicate that at $\approx 1 \mathrm{MAC}$ desflurane, like halothane, haemodynamic stability is maintained in neonates, infants and children.

Previous studies have shown that both animals and adult humans recover from desflurane anaesthesia very rapidly. ${ }^{5,26.27}$ Preliminary data in children are consistent with published data in adults. ${ }^{22}$ However, not all measures of recovery support our clinical impression that recovery after desflurane anaesthesia is more rapid than after other inhalational anaesthetics. For example, although the time to eye opening, $6.1 \pm 2.2 \mathrm{~min}$, was less than that reported after halothane or isoflurane in one study $(8.1 \mathrm{~min}),{ }^{16}$ it was similar to that reported after the same anaesthetics in another. ${ }^{14}$ Moreover, the time to full recovery after desflurane anaesthesia in this study is no different from that reported previously with halothane and isoflurane. ${ }^{14}$ The differences between the recovery from desflurane in the present study and that from halothane and isoflurane in previous studies may be attributed to (1) a 2-20-fold longer duration of anaesthesia in the present study than in previous studies, ${ }^{14,16,23}$ (2) greater anaesthetic concentration throughout surgery in this study (the anaesthetic concentration was maintained at $\approx 1 \mathrm{MAC}$ with $70 \% \mathrm{~N}_{2} \mathrm{O}$ until the completion of surgery), (3) differences in the definition of full recovery, and (4) the use of intramuscular codeine for postoperative analgesia. In a direct comparison of desflurane with halothane in children, Welborn et al. found a more rapid recovery after desflurane, but no difference in the time to discharge home. ${ }^{22}$ Similar findings have been reported in adults for desflurane and isoflurane. ${ }^{26} \mathrm{~A}$ direct comparison of desflurane and isoflurane in children for speed of recovery and time to discharge has not been undertaken. The inconsistency in the recovery from desflurane anaesthesia in infants and children suggests that further studies are required to determine whether desflurane holds any advantage over current anaesthetics in terms of recovery times.

In infants and children, airway reflex responses after extubation are causes for concern. In children, breathholding, coughing and laryngospasm occur during recovery from both isoflurane and halothane anaesthesia, although more frequently after isoflurane, particularly during awake extubations. ${ }^{14,15,29}$ In contrast, we found no episodes of airway reflex responses after awake extubations in infants and children who had been anaesthetized with desflurane. These results demonstrate that recovery from the respiratory effects of desflurane is complete at the time of extubation and that airway complications are unlikely to occur after extubation.

The washout of desflurane was rapid as evidenced by the $F / F_{A O}$ ratios at two and five minutes, $0.14 \pm 0.05$ and $0.06 \pm 0.04$ respectively. These values compare favourably with previous data for halothane and isoflurane in which the $F_{A} / F_{A O}$ ratios for the former were 0.58 and 0.48 at two and five minutes and those for the latter were 0.3 and 0.25 respectively. ${ }^{23}$ In adults, the washout of desflurane is more rapid than that of halothane and isoflurane but slower than that of desflurane in infants and children, achieving an $\mathrm{F}_{\mathrm{A}} / \mathrm{F}_{\mathrm{AO}}$ for desflurane in adults of $0.14 \pm 0.02$ by five minutes. ${ }^{4}$ These differences are not surprising when we consider that the ratio of alveolar ventilation to functional residual capacity in neonates and infants is greater than that in adults and that the solubility of inhaled anaesthetics in the blood and tissues of infants and children is less than that in adults. ${ }^{13,28}$ The small difference in the $F_{A} / F_{A O}$ ratios of desflurane between infants and children, and adults reflects the very rapid washout of this insoluble anaesthetic.

The washout of desflurane was similar in all six age groups (Figure). This is not surprising since (1) desflurane is relatively insoluble in adult tissues ${ }^{2}$ (and is expected to be less soluble in the tissues of infants and children $)^{28}$ and (2) the mean exposure to desflurane was brief ( $51.8 \pm$ $35.2 \mathrm{~min}$ ) therefore limiting tissue uptake to the vessel-rich and to a lesser extent, the muscle group. Therefore the effect of age on the washout of desflurane was not evident.

We conclude that although desflurane may not be suited for induction of anaesthesia in infants and children, it facilitates a very rapid recovery of consciousness without evoking airway reflex responses during emergence.

\section{Acknowledgements}

We thank Ms N. Sikich for her assistance during this study, Dr. R.E. Creighton for his editorial assistance and Anaquest BOC Inc. for their support.

\section{References}

1 Eger EI II. Partition coefficients for I-653 in human blood, saline and olive oil. Anesth Analg 1987: 66: 971-3.

2 Yasuda N, Targ AG, Eger EI II. Solubility of I-653, sevoflurane, isoflurane, and halothane in human tissues. Anesth Analg 1989; 69: 370-3.

3 Taylor RH, Lerman J. Minimum alveolar concentration (MAC) of desflurane and hemodynamic responses in neonates, infants and children. Anesthesiology 1991; 75: (in press).

4 Yasuda N, Lockhart SH, Eger El Il et al. Kinetics of desflurane, isoflurane and halothane in humans. Anesthesiology 1991; 74: 489-98. 
5 Eger EI II. Johnson BH. Rates of awakening from anesthesia with I-653, halothane, isoflurane, and sevoflurane: a test of the effect of anaesthetic concentration and duration in rats. Anesth Analg 1987; 66: 977-82.

6 Jones RM, Cashman JN, Mant TGK. Clinical impressions and cardiorespiratory effects of a new fluorinated inhalational anaesthetic, desflurane (I-653), in volunteers. $\mathrm{Br} \mathrm{J}$ Anaesth 1990; 64: 11-5.

7 Rampil IJ, Lockhart SH, Zwass MS, Eger EI II, Weiskopf $R B$. Damask $M C$. Clinical characteristics of desfluranc in surgical patients: minimum alveolar concentration. Anesthesiology 1991; 74: 429-33.

8 Weiskopf RB, Cahalan MK, Ionescu P et al. Cardiovascular action of desflurane with and without nitrous oxide during spontaneous ventilation in humans. Anesth Analg 1991; 73: 165-74.

9 Lockhart SH, Rampil IJ, Yasuda N, Eger EI II, Weiskopf $R B$. Depression of ventilation by desflurane (I-653) in humans. Anesthesiology 1991; 74: 484-8.

10 Jones RM, Koblin DD, Cashman JN, Eger EI, Johnson $B H$, Damask $M C$. Biotransformation and hepato-renal function in volunteers after exposure to desflurane (1-653). $\mathrm{Br} J$ Anaesth 1990: 64: 482-7.

11 Taylor RH, Bissonnette B, Atkinson GR. Anacsthetic data logging using a Psion pocket computer. Can J Anaesth 1990; 37: 386.

12 Broadman LM, Rice LJ, Hannallah RS. Testing the validity of an objective pain scale for infants and children. Anesthesiology 1988; 69: A770.

13 Lerman J, Gregory GA, Willis MM, Eger EI II. Age and solubility of volatile anaesthetics in blood. Anesthesiology 1984; 61: 139-43.

14 Fisher DM, Robinson S, Bren CM, Perin G, Gregory $G A$. Comparison of enflurane, halothane and isoflurane for diagnostic and therapeutic procedures in children with malignancies. Anesthesiology 1985; 63: 647-50.

15 Pandit UA, Steude GM, Leach $A B$. Induction and recovery characteristics of isoflurane or halothane for short outpatient operations in children. Anacsthesia 1985; 40: 1226-30.

16 Cattermole RW, Verghese C, Blair IJ, Jones CJH, Flynn $P J$, Sebel PS. Isoflurane and halothane for outpatient dental anaesthesia in children. Br J Anaesth 1986; 58: 385-9.

17 Phillips AJ, Brimacombe JR. Simpson DL. Anaesthetic induction with isoflurane or halothane. Anaesthesia 1988; 3: 927-9.

18 Lindgren L, Saarnivaara L, Himberg $J J$. Comparison of oral triclofos, diazepam, flunitrazepam as premedicants in children undergoing otolaryngological surgery. $\mathrm{Br} \mathrm{J}$ Anaesth 1980; 52: 283-9.
19 Raftery $S$, Warde $D$. Oxygen saturation during inhalation induction with halothane and isoflurane in children: effect of premedication with rectal thiopentone. Br J Anacsth 1990; 64: 167-9.

20 Eger EI Il. Isoflurane (Forane (B), a compendium and reference. 2nd ed. Madison: Anaquest BOC Health Care, 1985.

21 Crean PM, Laird CRD, Keilty SR, Black GW. The influence of atropine on isoflurane anaesthetics in children. Anesthesiology 1989; 71: A 1049.

22 Welborn L, Zwass MD. Cote C et al. Comparison of desflurane and halothane in pediatric ambulatory patients. Anesth Analg 1991; 72: S320.

23 Wren WS, McShane AJ, McCarthy JG, Lamont BJ, Carey $W F$, Hannon VM. Isoflurane in paediatric anaesthesia: induction and recovery from anaesthesia. Anaesthesia 1985; 40: 315-23.

24 Weiskopf RB. Holmes MA, Rampil IJ et al. Cardiovascular safety and actions of high concentrations of I-653 and isoflurane in swine. Anesthesiology 1989; 70: 793-8.

25 Lerman J, Robinson S, Willis MM, Gregory GA. Anesthetic requirements for halothane in young children 0-1 month and 1-6 months of age. Anesthesiology 1983; 59: $421-4$.

26 Ghouri $A F$, Bodner $M$, White $P F$. Recovery profile after desflurane-nitrous oxide versus isoflurane-nitrous oxide in outpatients. Anesthesiology 1991; 74: 419-24.

27 Smiley RM, Ornstein E, Matteo RS, Pantuck EJ, Pantuck $C B$. Desflurane and isoflurane in surgical patients: comparison of emergence time. Ancsthesiology 1991; 74: 425-8.

28 Lerman J, Schmitt-Bantel Bl, Gregory GA, Willis MM, Eger $E I I I$. Effect of age on the solubility of volatile anaesthetics in human tissues. Anesthesiology 1986; 65: 307-11.

29 Pounder DR, Blackstock D, Steward DJ. Tracheal extubation in children: halothane versus isoflurane, anesthetized versus awake. Anesthesiology 1991; 74: 653-5. 